\title{
Critical Theory and Pleasure in Herbert Marcuse
}

\section{Mandara L}

Università degli Studi di Napoli “Federico II”, Italy

*Corresponding author: Luca Mandara, Università degli Studi di Napoli "Federico II", Italy, Tel: 3388664289; Email: luca.mandara@unina.it

\section{Research Note \\ Volume 4 Issue 1}

Received Date: February 01, 2021

Published Date: March 08, 2021

DOI: $10.23880 /$ phij-16000164

\section{Abstract}

These pages try to retrace the philosophical background of the concepts of happiness and pleasure in Herbert Marcuse's Critical Theory. I would argue, in fact, that they can still provide us with a key to reading the politics of pleasure of our time.

Nowadays, indeed, it seems that people are asked to accept austerity and sacrifice at work in change of the extraordinary wide world of commodities, advertising and Hi-Tech goods. Besides, they are also supposed to enjoy something like YouPorn and, at the same time, to tolerate the supporters of the patriarchal family or, worst case scenario, to support it activelya. Exploitation and sacrifice, consumerism and spectacularism ${ }^{\mathrm{b}}$, traditionalist movements: the integration of so contradictory politics and moralities in the same whole is shocking.

Reading again Herbert Marcuse on this issue is not naïve. Well before he integrated Freud's theory into Marxism, Marcuse had already made pleasure one of the main concerns of his Critical Theory in the essays The Affirmative Character of Culture and On Hedonism from the 1930s, whether not his peculiar contribute to it ${ }^{c}$. According to him, happiness, which comes from pleasure, was the main goal of the «struggle for a rational society» ${ }^{d}$. To be sure, as stated by Marcuse himself, this was due to historical reason. As far as happiness and pleasure had become objects of false promises and mechanisms of domination by capitalism, they were to become object of a struggle of liberation: the Great Refusal of Eros and Civilization.

Keyword: Herbert Marcuse's; Critical Theory; Happiness; Pleasure

aIt is for many years that the International Organization for the Family propagandises a rigid morality over sexuality (mainly against homosexuals and LGBTs); the return to a closed and patriarchal family; a strict education of children. Useless to say that it is quite supported by many Right Populist Leaders like Victor Orbán and Matteo Salvini who attended some of their congresses. During the 13th Congress in Verona of the last March, there was a quite widespread mobilization of the Italian civil society and public opinion against their presence and their manifestos.

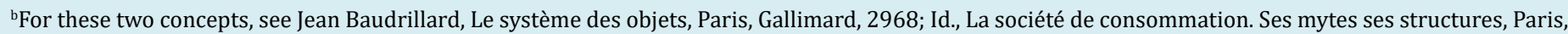
Gallimard, 1974; Guy Debord, La Société du Spectacle. Commentaires sur la Société du Spectacle, Paris, Gallimard, 1992.

'This is the idea of Stefano Petrucciani, Felicità e ragione. Il contributo di Marcuse all'idea di teoria critica, in Leonardo Casini (a cura di), Eros, Utopia e Rivolta. Il pensiero e l'opera di Herbert Marcuse, Milano, FrancoAngeli, 2004, pp. 138-151.

${ }^{\mathrm{d} H e r b e r t}$ Marcuse, On Hedonism (1938), in Id., Negations. Essays in Critical Theory (1968), ed. by Jeremy J. Saphiro, London, MayFlyBooks, 2009 , p. 147.

\section{Critical Theory and the Concrete Individuality}

In the 1930s, Marcuse's Critical Theory is committed to look for a "transcendence" inside the dominating society. This is due to its nature as thought by Marcuse in these years. According to him, every theory is never neutral, but «an element of the social process of life, borne by particular historical interests» ${ }^{1}$. Yet, unlike the other theories or philosophies, the Critical Theory is also conscious of the

1 Id., The Concept of Essence, in Id. Negations, cit., p. 57. 


\section{Philosophy International Journal}

social subject who it aims to: « no longer the isolated, abstract individual at the basis of idealist philosophy [...]. Theory has moved to another subject; its concepts are generated by the consciousness of specific groups and individuals who are part of the fight for a more rational organization of society» ${ }^{2}$. Then, this theory is critical since it is the theory of a social transformation which negates the existing society opposing to it a more rational one ${ }^{3}$. As a consequence, the negative praxis orients the theorical interest toward every negative potentiality within the limits of the established order. Critical Theory understands these negative aspects as negative truths, whosevalidity is neither a priori, nor immediately $a$ posteriori, but measured on what is historically possible and necessary to build a more rational society. At the same time, reason itself is, for Marcuse, critical in its essence. It is the faculty which does not accept the existence of the "facts" as law, but it criticizes them in a double sense: retracing their historical origins and comparing them with the new historical possibilities in the name of happiness.

«The rationalist theory of society is therefore essentially critical; it subjects society to the idea of a theoretical and practical, positive and negative critique. This critique has two guidelines: first, the given situation of man as a rational organism,i.e.one that has the potentiality offreely determining and shaping his own existence, directed by the process of knowledge and with regard to his worldly happiness; second, the given level of development of the productive forces and the (corresponding or conflicting) relations of production as the criterion for those potentialities that can be realized at any given time in men's rational structuring of society» ${ }^{4}$.

Thanks to this critical nature of reason, Critical Theory can keep a relative autonomy respect to praxis, guide and even condemn it if it betrays its rational goals ${ }^{5}$. In fact, «a

\section{Ibid.}

3 To be sure, Marcuse thought that a free society had to be based on a rational organization of the productive forces, that is of the "reign of necessity". He ever followed Marx in the main features of this organization: «the disposal over the means of production by the community, the reorientation of the productive process toward the needs and wants of the whole society, the shortening of the working day, and the active participation of the individuals in the administration of the whole» (see H. Marcuse, On Hedonism, in Id., Negations, cit., 144).

4 H. Marcuse, The Struggle Against Liberalism in Totalitarianism, in Id., Negations, cit., pp. 9-10.

5 It is well known that the "first generation" of the Frankfurt School, in particular Max Horkheimer, Theodore W. Adorno and Herbert Marcuse, always claimed for a relative autonomy of the theory respect to the praxis. According to them, this was ever more necessary due to the progressive deterioration of the dialectic power of the proletariat, the social subject whose action had supported the Marxian project of a rational society against the irrationality of capitalism. See Alfred Schmidt, Gian Enrico Rusconi, La scuola di Francoforte. Origini e significato attuale, Bari, De Donato, 1972; Martin Jay, The Dialectical Imagination. A history of the Frankfurt School and the Institute of Social Research 1923-1950, London, Heinemann, 1976; theory of society is rationalist when the practice it enjoins is subject to the idea of autonomous reason, i.e. to the human faculty of comprehending, through conceptual thought, the true, the good, and the right $»^{6}$. Therefore, the need for reason and, at the same time, for autonomy, is always connected with the request of happiness. Like reason, happiness is a philosophical universality never identifiable with a particular order ${ }^{7}$. In Marcuse's Critical Theory they become negations to every historical society which pretends to be "the end of history" or the "realization of reason". They have to be thought like "regulative ideas", commitments for rational men more than real stages of humanity.

Yet, to the opposite side of philosophical universalities, there is another negative concept in Marcuse's Critical Theory in these years. According to The Affirmative Character of Culture and On Hedonism, the (relative) realization of reason and happiness in the history requires the liberation of the concrete individuality, where concrete means rich of needs and faculties, mainly the sensuous ones, and, at the same time, being social.

Following Marcuse's pages, the concreteness of individuals appears to be the most repressed in the capitalistic society since its very beginning. This could sound very weird as the bourgeoise society presented itself as the liberation of the individuality from the social chain of personal domination of feudalism. In true, according to Marcuse, this freedom would reveal soon just as free competition and then as a reciprocal slavery to the market of commodities. Now, the social being of man is its private being, that is isolated and abstract from society. In this world, the individuality acquires its social character only in its isolation from society and then from its concrete being. If it is true that the bourgeoise society grounds on the liberation of individuals, these ones are just «independent, self-sufficient $\operatorname{monad} »^{8}$.

The consequence of this reciprocal isolation is, however,

Rolf Wiggershaus, Die Frankfurter Schule, Reinbek, Rowohlt Taschenbuch Verlag, 2010.

6 H. Marcuse, The Struggle Against Liberalism in Totalitarianism, p. 9. Since Critical Theory wants to be a materialistic theory, «the 'autonomy of reason' definitely does not mean setting reason as the absolute ground or essence of what is. To the extent, rather, that reason is comprehended as the reason of concrete individuals in their specific social situation, the 'material' conditions of this situation enter into the conditions of the rational practice that is required. But these conditions as well are to be comprehended rationally and, on the basis of this comprehension, to be transformed» (ibid., p. 19, footnote 25).

7 On the role of philosophical universalities, see Herbert Marcuse, Douglas Kellner, One Dimensional Man. Studies in the Ideology of Advanced Industrial Society, Boston, Beacon Press, 1991.

8 H. Marcuse, The Affirmative Character of Culture, in Id. Negations, cit., p. 82. 


\section{Philosophy International Journal}

the necessity of social mediators to relate the members of the society. In the bourgeoise society «the prevailing social relationship is the relation of men to one another as owners of commodities ${ }^{9}$, first of all their own labour force. Consequently, the individuals are not immediately related to each other, but rather to the market "(without his personal qualities and needs being relevant except as commodities) ${ }^{10}$. In the market, the concrete, particular, useful labour is reduced to the abstract labour, the quantity of time necessary to produce a good. It is the common measure of the "value" of the commodities, the abstract equivalent that makes possible to exchange different works through different commodities. Only thanks to the mediation of this abstraction individuals enter this society, and only having it they can access to consumption. In fact, their work is not in their full disposal. It belongs to capitalists, the owners of the means of production and subsistence, who exploit work to accumulate abstract value for its sake. In the end, labour is completely and violently divided from the moment of consumption.

As a consequence, in the bourgeoise social relation, the concrete individuality, with its multiple richness of individual qualities and needs, does not have "value", neither in the social (universal) side of work, nor in the individual moment of consumption, that is enjoyment. The whole society has to be committed to the abstraction of the concrete individuality from society and from itself. He must be reduced to an abstract "thing" as the other world. Society must discipline every claim for a free development of individual sensuality in the concrete social relation. In particular, pleasure is the worst enemy in this tendency to capitalistic abstraction.

\section{Critical Theory and Pleasure}

In a society where wealthy is produced reducing the individual and the social body to an abstraction, pleasure of senses is prohibited, and then it can become a negation. On one side, the realization of pleasure would require concrete social relation and then overcoming the monadic bourgeoise isolation. «Enjoyment», indeed, «is an attitude or mode of conduct toward things and human beings» ${ }^{11}$. On the other side, it would also require a society committed to promote the individuality rather than repress it. "Pleasure», in fact, «wants essentially its own augmentation and refinement» ${ }^{12}$.

These requests are unsatisfiable by capitalism. They would substitute the abstract labour to measure social

9 Id., On Hedonism, cit., p. 138.

10 Id., The affirmative character of culture, cit., p. 69.

11 Id., On Hedonism, cit., p. 137.

12 Ibid. richness rather in terms of receptivity than productivity. «Social justice would be called into question. Indeed, it would reveal itself as striking injustice» ${ }^{13}$. In the name of pleasure masses would refuse the material misery and the ethic of labour, the "self-justification of the will to labour" $»^{14}$. To be sure, pleasure and pain do not oppose against work as a whole, but «are withdrawn from any justification or motivation by the will to labour; rather, they provide this will with the "stimulus to labour", which would then be subsumed under the principle of the satisfaction of wants» ${ }^{15}$. An "ethic of pleasure" would require, essentially, a satisfying work in its process ${ }^{16}$.

Moreover, this critical side of pleasure would become far more severe because its demands could be not only realized, but also developed further thanks to the technical progress of the capitalistic society. According to Marcuse, indeed, the human sensibility is historical and its features are defined, on one hand, by the technical progress of society; on the other hand, by the social relation where it is accomplished: "Industrial society has differentiated and intensified the objective world in such a manner that only an extremely differentiated and intensified sensuality can respond adequately to it. Modern technology contains all the means necessary to extract from things and bodies their mobility, beauty, and softness in order to bring them closer and make them available. Both the wants corresponding to these potentialities and the sensual organs through which they can be assimilated have been developed. What man can perceive, feel, and do in the midst of advanced civilization corresponds to the newly opened up wealth of the world $»^{17}$.

Nonetheless, «the development of sensuality is only one part of the development of the productive forces: the need to fetter them is rooted in the antagonistic social system within which this development has taken place ${ }^{18}$. The social antagonism is the fundament of the necessity to chain the free unfolding of sensibility down and, as a consequence, to repress the reality of a world of fulfilment. Society has to violently divide the inner connection between work and pleasure, social relation and individual satisfaction in order to restore its prerequisite: the isolation of the abstract individuality.

\footnotetext{
13 Ibid., p. 138.

14 Ibid., p. 140

15 Ibid.

16 The idea of a "stimulus to labour" is one of the main topics of Eros and Civilization. It is inspired from the utopian socialist idea of the transformation of labour into play, coming from Charles Fourier and discussed by Marx too. On this, see Ferruccio Andolfi, Lavoro e libertà. Marx, Marcuse, Arendt, Parma, Diabasis, 2004.

17 H. Marcuse, On Hedonism, cit., p. 137.

18 Ibid., pp. 137-138.
} 


\section{Philosophy International Journal}

\section{The Internalization of Pleasure}

Free competition and political violence are the main ways to isolate the individuals each other, but not the only ones. Other social institutions and the dominant culture cooperate to this purpose. For Marcuse, the Affirmative Culture and the Hedonism are two "figures of the discipline" of sensual enjoyment. Both imply the connection between pleasure and happiness, but they neutralize them in two opposite ways: the former, internalizes happiness making it an abstract ideal of the "soul"; the latter, externalizes happiness in the immediate satisfaction of every needs and desires.

In The Affirmative Character of Culture, Marcuse analyses the strategy of the internalization of happiness. As said, in the bourgeoise society the concrete individuality is denied to develop himself freely in the external social relation. However, the bourgeoise culture establishes a refuge for him: the intimacy of the soul, the indefinite world of the feeling, of the "subjectivity" that (still) escapes from the rationalization of the production. The idea of "soul" expresses this "immaterial" remain of a rationalized materiality to the purposes of the abstract labour. Then, the soul is a negative reference against the dehumanized and reificated real world:

"And in this - negative - quality it now becomes the only still immaculate guarantor of bourgeois ideals [...]. The ideal that man, individual, irreplaceable man, beyond all natural and social distinctions, be the ultimate end; that truth, goodness, and justice hold between men; that all human weaknesses be expiated by humanity - this ideal can be represented, in a society determined by the economic law of value, only by the soul and as spiritual occurrence» ${ }^{19}$.

However, even if «affirmative culture uses the soul as a protest against reification $»^{20}$, it is also true that «because it is exempted from reification, it suffers from it least, consequently meeting it with the least resistance»» ${ }^{21}$. According to the ideal of the soul, in fact, «the soul alone obviously has no exchange value. The value of the soul does not enter into the body in such a way as to congeal into an object and become a commodity» ${ }^{22}$. The protest of the souls is false and its culture is affirmative, because it justifies the dominant society. It does not want to transform the exterior misery which affects the concrete and sensual individuality, but rather to elevate the latter to some "sublime" "human" relations. Within the purely inner space of the soul, every request of humanization of the material relation, first of all

19 Id., The Affirmative Character of Culture, cit., p. 80.

20 Ibid., p. 80.

21 Ibid., p. 83.

22 Ibid., p. 80. of labour, is disciplined. The Bildung ${ }^{23}$, fundament of the affirmative culture, is just an education to «resignation ${ }^{24}$ :

«The ideal, to be sure, was conceived in such a fashion that its regressive and apologetic, rather than its progressive and critical, characteristics predominated. Its realization is supposed to be effected through the cultural education of individuals. Culture means not so much a better world as a nobler one: a world to be brought about not through the overthrow of the material order of life but through events in the individual's soul. Humanity becomes an inner state. Freedom, goodness, and beauty become spiritual qualities: understanding for everything human, knowledge about the greatness of all times, appreciation of everything difficult and sublime, respect for history in which all of this has become what it is. This inner state is to be the source of action that does not come into conflict with the given order. Culture belongs not to him who comprehends the truths of humanity as a battle cry, but to him in whom they have become a posture which leads to a mode of proper behaviour: exhibiting harmony and reflectiveness even in daily routine. Culture should ennoble the given by permeating it, rather than putting something new in its place. It thus exalts the individual without freeing him from his factual debasement ${ }^{25}$

To be sure, sensibility is the main individual faculty to be exalted and spiritualized in order to avoid any request of material enjoyment. Here, the proper purpose of the culture of the soul is accomplished: to make individuals able to discipline their material need of happiness on their own by «the internalization of enjoyment through spiritualization ${ }^{26}$. This occurs accepting happiness in the culture only when it comes from the contemplation of artistic beauty.

Marcuse, indeed, agrees with «Stendhal's assertion that beauty is "une promesse de bonheur" ${ }^{27}$. In the affirmative culture, however, «enjoyment of happiness is permitted only in spiritualized, idealized form $»^{28}$. But the affirmative ideal «is insensitive to happiness» ${ }^{29}$ : it is the negation of sensibility. «Idealization», in fact, «annuls the meaning of happiness. For the ideal cannot be enjoyed, since all pleasure is foreign to it and would destroy the rigor and purity that must adhere to it in idealess reality if it is to be able to

23 On the relations between Marcuse and the German Classical Aesthetics, see Roberta Ascarelli, Marcuse e I classici Tedeschi, in L. Casini (a cura di), Eros utopia e rivolta, cit., pp. 123-137.

24 Id., The Affirmative Character of Culture, p. 80.

25 Ibid., p. 76.

26 Ibid., p. 81.

27 Ibid., p. 85.

28 Ibid., p. 88.

29 Ibid. 


\section{Philosophy International Journal}

carry out its internalizing, disciplining function» ${ }^{30}$. The appearance (Schein) of artistic beauty is the solution of this contradiction. The beautiful form of art «gives the ideal the character of the charming, the gladdening, and the gratifying - of happiness» ${ }^{31}$. In this way, art represents an ideal world of humanity which it can oppose to that material one dominated by exchange value. In this sense, it is a negative force. Yet, dialectically, it makes individuals love those ideals that are to discipline and repress them. The artistic world must be just ideal, never real, otherwise it would leave its sublimity. Although this repressive idealization of happiness, «this illusion has a real effect, producing satisfaction» ${ }^{32}$. Art reconciles individuals with the world offering to the former a constant reproduceable way of escaping the repression of the latter. Art becomes «the real miracle of affirmative culture. Men can feel themselves happy even without being so at all» ${ }^{33}$. Therefore, art has a repressive function ${ }^{34}$ :

«The latter's meaning [of satisfaction], though, is decisively altered; it enters the service of the status quo. The rebellious idea becomes an accessory in justification. The truth of a higher world, of a higher good than material existence, conceals the truth that a better material existence can be created in which such happiness is realized. In affirmative culture even unhappiness becomes a means of subordination and acquiescence. By exhibiting the beautiful as present, art pacifies rebellious desire. Together with the other cultural areas it has contributed to the great educational achievement of so disciplining the liberated individual, for whom the new freedom has brought a new form of bondage, that he tolerates the unfreedom of social existence. The potentiality of a richer life, a potentiality disclosed with the help of modern thought, and the impoverished actual form of life have come into open opposition, repeatedly compelling this thought to internalize its own demands and deflect its own conclusions. It took a centuries-long education to help make bearable the daily reproduced shock that arises from the contradiction between the constant sermon of the inalienable freedom, majesty, and dignity of the person, the magnificence and autonomy of reason, the goodness of humanity and of impartial charity and justice, on the one hand, and the general degradation of the majority of mankind, the irrationality of the social life process, the victory of the labour market over humanity, and of profit over charity, on the other. "The entire counterfeit of transcendence and of the hereafter has grown up on the basis of an impoverished life ...", but the injection of cultural

\footnotetext{
30 Ibid.

31 Ibid., p. 89.

32 Ibid.

33 Ibid., p. 90.

34 On the Marcuse's change of perspective on art, see Elena Tebano, Estetica e rivoluzione: la funzione politica dell'arte in Herbert Marcuse (1945-1955), in L. Casini (a cura di), Eros, utopia e rivolta, cit., pp. 152-172.
}

happiness into unhappiness and the spiritualization of sensuality mitigate the misery and the sickness of that life to a 'healthy' work capacity» ${ }^{35}$.

\section{The Externalization of Pleasure}

Against this world of intimacy, Hedonism opposes the material pleasure of the body: pleasure is the satisfaction of material needs; happiness is the result of the addition of these pleasures; being happy means feeling material pleasure. As a result, Hedonism is progressive respect to the spiritualization of enjoyment of the affirmative culture: its refuse of intimacy as space of realization moves the claim for freedom toward the sphere of the material external relations:

«It is against this internalization of happiness, which accepts as inevitable the anarchy and unfreedom of the external conditions of existence, that the hedonistic trends of philosophy have protested. By identifying happiness with pleasure, they were demanding that man's sensual and sensuous potentialities and needs, too, should find satisfaction - that in them, too, man should enjoy his existence without sinning against his essence, without guilt and shame. In the principle of hedonism, in an abstract and undeveloped form, the demand for the freedom of the individual is extended into the realm of the material conditions of life. Insofar as the materialistic protest of hedonism preserves an otherwise proscribed element of human liberation, it is linked with the interest of critical theory» ${ }^{36}$.

In addition, the hedonistic demand of sensual pleasure, material freedom, concrete satisfaction meets with Critical Theory's fight against the ideologies of sacrifice. Hedonism is a critical perspective against every abstract and reified universality, including the "community", which, in the name of superior "reasons", imposes the sacrifice of individuality. Here, happiness is thought like a strictly individual need and then it cannot coincide with anything prior the concrete individuals. As a consequence, a society which imposes a particular way of happiness without any regard to the individuality, is false: «general happiness apart from the happiness of individuals is a meaningless phrase ${ }^{37}$. The hedonistic concept of happiness is, for this aspect, negative. «Hedonism is useless as ideology and in no way admits of being employed to justify an order associated with the suppression of freedom and the sacrifice of the individual» ${ }^{38}$.

However, according to Marcuse the hedonistic protest

35

36

37

38
Id., The Affirmative Character of Culture, p. 90.

Id., On Hedonism, cit., p. 121.

Ibid.

Ibid., p. 124. 


\section{Philosophy International Journal}

remains abstract since it accepts, as well as idealism, the sharp division between happiness and reason, individuality and society. Hedonism legitimizes that division because of its private concept of happiness and pleasure. Needs, whose satisfaction coincides with happiness, are beyond good and evil, true and false: every need, regardless its concrete determination, must be satisfied, because every satisfaction brings, finally, happiness. «This hedonism fails to differentiate not only between individual pleasures but also between the individuals who enjoy them. They are to gratify themselves just as they are, and the world is to become an object of possible enjoyment just as it is» ${ }^{39}$. Then, the measure of happiness is what the individuals and the world are now and not what they could be. This concept of happiness loses its critical side since Hedonism transforms something of historical, like the needs, into something of "natural" to be satisfied just because given: a fact. Refusing the rational power to judge and to distinguish, Hedonism cannot understand that those individuals, whose satisfaction is demanded against reified universalities, are already reified because their needs are already repressed by the society:

«Hedonism is not untrue because the individual is supposed to seek and find his happiness in a world of injustice and of misery. To the contrary, the hedonistic principle as such rebels often enough against this order. If it were ever to take hold of the masses, they would scarcely tolerate unfreedom and would be made completely unsuited for heroic domestication. The apologetic aspect of hedonism is located at a deeper level. It is to be found in hedonism's abstract conception of the subjective side of happiness, in its inability to distinguish between true and false wants and interests and between true and false enjoyment. It accepts the wants and interests of individuals as simply given and as valuable in themselves. Yet these wants and interests themselves, and not merely their gratification, already contain the stunted growth, the repression, and the untruth with which men grow up in class society. The affirmation of the one already contains the affirmation of the other» ${ }^{40}$.

The abstraction affects the hedonistic concept of sensibility and pleasure. Hedonism refers «happiness to immediate abandon and immediate enjoyment ${ }^{41}$. This is the unique form of enjoyment which is permitted in the limit of an antagonistic society where individuals do not rationally govern the production according to their need. Reason is separated from individuals, and then from their concreteness. Here, in fact, like Hegel understood in a philosophical concept, «reason rules only behind the backs of individuals in the reproduction of the whole that takes place

\footnotetext{
39 Ibid., p. 122

40 Ibid., p. 126.

41 Ibid., p. 122.
}

despite anarchy» ${ }^{42}$. In this scenario, the living conditions appear casual to the individuals because they are so. As a consequence,

«happiness is encountered as something withdrawn from the autonomy of the individual, something that can be neither achieved nor controlled by reason. The element of extraneousness, contingency, and gratuitousness is here an essential component of happiness. It is just in this externality, in this innocent, unburdened, harmonious conjunction of the individual with something in the world, that pleasure consists. In the historical situation of individuals up to the present, it is not what reason has achieved nor what the soul experiences that can be called happiness (for these are necessarily tainted with unhappiness). To the contrary, only 'externalized' pleasure, i.e. sensuality, can be called happiness. In reified social relationships, sensuality, and not reason, is the 'organ' of happiness» ${ }^{43}$.

Sensibility, in fact, is receptivity, whose main feature is an «open abandon to objects (men and things)» ${ }^{44}$. Sensibility opens the isolation of the individuality and, as a consequence, it breaks the bourgeoise isolation. But this break is accidental, casual, subjective and immediate because of the universal and irrational conditions of production. As a result, individuals can meet with objects «without their essential mediation through the social life process and, consequently, without their unhappy side becoming constitutive of pleasure ${ }^{45}$. Hedonism, as well as the Affirmative Culture, gives the appearance of happiness to the individuals hiding the universal unhappiness of the social being. This pleasure is a false rupture and it works to reproduce the isolation.

«Hedonism wants to preserve the development and gratification of the individual as a goal within an anarchic and impoverished reality. But the protest against the reified community and against the meaningless sacrifices which are made to it leads only deeper into isolation and opposition between individuals as long as the historical forces that could transform the established society into a true community have not matured and are not comprehended. For hedonism, happiness remains something exclusively subjective. The particular interest of the individual, just as it is, is affirmed as the true interest and is justified against every and all community. This is the limit of hedonism: its attachment to the individualism of competition. Its concept of happiness can be derived only by abstracting from all universality and community. Abstract happiness corresponds to the abstract

\footnotetext{
$42 \quad$ Ibid., p. 129.

43 Ibid., p. 127.

44 Ibid., p. 128.

45 Ibid.
} 


\section{Philosophy International Journal}

freedom of the monadic individual. The concrete objectivity of happiness is a concept for which hedonism finds no evidence ${ }^{46}$.

In the end, to a deeper analysis, Hedonism advocates a pleasure which is essentially acceptable (or desirable) by the established order. Consumption elevated to a life-style would prove itself able to conciliate individuals and world through the immediate pleasure of senses. Here, in the individual sphere of consumption, people can find a sense in the universal non-sense of the labour machine of the capitalistic society. Eventually, the ascetism of labour does not contradict itself the research of this happiness.

\section{Pleasure as a Principle of Judgement}

On Hedonism, as well as the other essays from the 30's, grounds on the critical performance of Reason ${ }^{47}$. The final reconceptualization of happiness is based on the idea of a new society which organizes rationally its material forces in accordance with the satisfaction and the free development of the individual and collective potentialities. Since this historical possibility, rationally understood, it is possible to tell between true and false happiness and pleasure. Happiness is no longer « a mere subjective state of feeling» ${ }^{48}$, but it becomes an objective quality of a «happier real state of humanity» ${ }^{49}$ based on a rational organization of the production governed by the individuals according to their needs. This does not conciliate immediately every individual need with the social interest, but rational individuals would be free to choose together even the limits to their own individual satisfaction. Reason, namely the Community, is the ground of individual pleasure.

According to Marcuse himself, the tragic end of the Civil War in Spain and the trials in Moscow, played a decisive role in his trust in the emancipatory potentialities of the working class $^{50}$. The age of terror begun with the defeat of the promise of freedom and happiness through the conquest of reason embodied by the Marxist proletariat. At the same time, after

\section{Ibid., p. 125.}

47 On the full concept of Reason in Marcuse, see Herbert Marcuse, Reason and revolution. Hegel and the Rise of Social Theory, New York, Oxford University Press, 1941. On the change of his perspective to it in Eros and Civilization, see Leonardo Casini, Marcuse Maestro del '68, Roma, Il Poligono, 1981, p. 151. For a full retracement of it in Marcuse's work, see Gianluigi Palombella, Ragione e immaginazione. Herbert Marcuse 19281955, Bari, De Donato, 1982; Douglas Kellner, Herbert Marcuse and the Crisis of Marxism, Berkeley and Los Angels, University of California Press, 1984; Andrew Feenberg, "Marcuse: Reason, Imagination, and Utopia" in Radical Philosophy Review, Vol. 21, Issue 2, 2018, pp. 271-298.

48 Id., On Hedonism, p. 147.

49 Ibid., p. 143.

50 See Id., Foreword in Id., Negations, cit., p. XX. the Second World War, capitalism was reaching a new stage of stabilization characterized by the conquest of needs and desires of individuals through commodities.

In this historical contest, Marcuse, following the fundamental insight of his colleague Max Horkheimer and Theodore Adorno, discovered the Freud. To Marcuse, indeed, this age turned out to be a new "totalitarianism": the extension of the process of reification from the social dimension to the private sphere of individual desire. As a consequence, the process of emancipation is no longer played just in the traditional spheres, like economy and politic, but it requires a radical change in the subjectivity of individuals too: in their needs, desires, imaginations. In the philosophical terms of $\mathrm{On}$ Hedonism: only the emancipation of sensibility (subjectivity) supports the emancipation of reason (objectivity). Said that freeing sensibility does not mean a true freedom for itself, the chapter The Aesthetic Dimension of Eros and Civilization inquires what a free sensibility is, and what is the process of its emancipation. Here, the decisive concept is the "free play" of imagination ${ }^{51}$.

Marcuse retraces the foundations of a complete conception of sensibility in the German Classical Aesthetics (Baumgarten, Kant, Schiller). In particular, the Critique of Judgement by Kant plays a fundamental role in Marcuse's discussion. The Copernican Revolution of the third critique, is identified in the key role played by the aesthetic dimension, that is the one of imagination: mediating between the opposed (and conflictual) reign of necessity and freedom, knowledge and practice, senses and reason. Then, aesthetic imagination faces with the same problem of On Hedonism - the conflict between reason and happiness, society and individuality - where it was still solved with the emancipation of the proletariat.

In brief, imagination is connected with receptivity, the capacity of sensuousness (Sinnlichkeit) to be modified. In the case of aesthetic imagination, this modification is due not as much to the material of the external world (Empfindung), as to the inner receptivity of the feeling (Gefühl) of pleasure and pain: to the "aesthetic dimension". This aesthetic receptivity depends on the representation of beauty that is «the work (or rather the play) of imagination ${ }^{52}$. To be sure, in Kant this pleasure is still "pure", while, «in Schiller's Letters on the Aesthetic Education, the stress is on the impulsive, instinctual

51 On the key role of Aesthetics for liberation, see Alfredo De Paz, La dialettica dell'estetica. Saggio sul pensiero estetico di Herbert Marcuse, Bologna, Ponte Nuovo, 1972; Leonardo Casini, Eros e utopia. Arte, sensualità e liberazione nel pensiero di Herbert Marcuse, con Prefazione di Giacomo Marramao, Roma, Carrocci, 1999; Malcolm Miles, Herbert Marcuse. An Aesthetics of Liberation, London, Pluto Press, 2012.

52 Id., On Hedonism, p. 178. 


\section{Philosophy International Journal}

character of the aesthetic function $»^{53}$, directly connected with the faculty of desire: the play of imagination becomes the play impulse (Spieltrieb). Nonetheless, it remains true that the pleasure of beauty comes from the form of the object. In this way, the aesthetic pleasure or, that is quite the same, the play impulse, has a formal element that can demand a universality and a necessity unknown to the immediate pleasure coming from the hedonistic immediate satisfaction of desires (i.e. sexuality) or needs.

Therefore, as aesthetic function, the imagination reveals a formative capacity that would recall, in a weird analogy, the one of the "higher" faculties of the mind. This is the full meaning of the term sensuousness (Sinnlickeit) used for the foundation of aesthetics. "Here, the term designates the "lower" ("opaque," "confused") cognitive faculties of man plus the "feeling of pain and pleasure," - sensations plus affections ${ }^{54}$. So, when the impulsive force of desire reaches the stage of aesthetic imagination, it becomes able to provide reality principle. "In the aesthetic imagination, sensuousness generates universally valid principles for an objective order» ${ }^{55}$.

For Marcuse, Kant's idea recalls the Freudian conception of imagination where fantasy remains free from the reality principle and then it is free of showing the repressed desires of pleasure even in the highest production of culture, like art. With Kant, this mediations means that «the aesthetic dimension must contain principles valid for both realms» ${ }^{56}$. In its free play with the intellect, the imagination follows two principles. The "purposiveness without purpose", according to which the object is freed from the cognitive and practical need of the subject. As a consequence, it becomes free to develop its concrete individuality. The "lawfulness without law", the subjective side of the former, according to which the concrete individuality is free to look for a law by himself, through imagination and pleasure, without being oppressed by the higher faculties. Senses seems to be able to promote an order of the senses as well as reason. In this harmony, aesthetic imagination proves to be able to support a new morality, a new culture: an «aesthetic culture» ${ }^{57}$

Kant and Schiller's concept of play makes possible to rethink the Freudian concept of pleasure, too limited to immediate sexuality, toward a more complex idea of pleasure: Eros. The latter has to be thought like an appetitive-cognitive

\footnotetext{
53 Ibid., p. 183.

54 Ibid.

55 Ibid., p. 178.

56 H. Marcuse, Eros and Civilization: Philosophical Inquiry into Freud, Boston, Beacon Press, 1966, p. 177,

57 Ibid., p. 190.
}

power that is different as much from the "raw" individualistic desire of Hedonism, as from the conceptual and idealistic knowledge of Rationalism. Eros is the power of libido, where it origins, to self-sublimate into something similar to a knowledge and to a will, but it does not coincide with any of them even though it seems to change them. Indeed, aesthetic imagination, expression of Eros, aims to de-sublimate the sphere of the existence, necessity and freedom, work and morality, toward a less repressive principle of existence. The play transforms production and will like they would be if they were ruled by the value of beauty: a «libidinal work» ${ }^{58}$ and a «libidinal morality» ${ }^{59}$.

Since these reading, the liberation of imagination (play), which means the liberation of aesthetic subjectivity, becomes a fundamental concept in Marcuse's Critical Theory.

From Eros and Civilization, indeed, Marcuse would use the concept of play to measure the freedom and truth of the society. It is used like a "regulative idea" to criticize the dominant civilization as irrational and repressive and to draw a happier and less repressive future society, the final goal of emancipation. The feeling is not just, like in Kant's Critique of Judgment, the sign that it is to look for a universality for the individuality but, more with Shiller's idea, a universality itself which comparing the historical situation with. In some way, Marcuse's historical judgement becomes an aesthetic one: the historical individuality is subsumed under the aesthetic universality (the free play of faculties) and so measured in its "humanity". It is worthy to say that this "rule" of judgement breaks with Western productivism since freedom is thought to be the liberation of the senses more than the liberation from them. It demands more rest and restoration of the past than sacrifice for a senseless innovation of the future. The circle of play curves the unlimited line of development to reconcile humanity with what it is already become.

Moreover, if this feeling of pleasure is the free play of imagination, that is a psychic force of mankind, then it can well be already a negative force against the domination. The liberation of desires as enforcement of imagination, then, becomes a practical force of liberation now and here. The aesthetic subjectivity becomes expression of the Great Refusal, something that is necessary and possible to develop before every universal change of the structure of the society. It occurs everywhere and whenever individuals and groups break «with their familiar, the routine ways of seeing, hearing, feeling, understanding things so that the organism may become receptive to the potential forms of a non-aggressive, non-exploitative world $»^{60}$. Revolts, whose relationship with

$58 \quad$ Ibid., p. 217.

59 Ibid., p. 229.

60 H. Marcuse, An Essay on Liberation, Boston, Beacon Press, 1969, p. 10. 
The Revolution is still being decided ${ }^{61}$.

\section{Conclusions}

In conclusion, the several moralities offered by the current market (the ascetism implied in the austerity policies and in the traditionalist movements; unrestrained pleasure of consumerism) are anything but different social disciplines. They can coexist and cooperate in their contradiction to reproduce the antagonistic system which generates them. Marcuse would agree with the Marxian thesis that the contradiction between labour and satisfaction, production and consumption, is the reality of the division of labour, and only abolishing the latter is possible to solve the former. Beyond Marx, however, Marcuse thought that was worthy to pay particular attention to every revolt for a radical change in our desires, needs, customs as the beginning of a radical change. It is not by chance that

61 See Id., Counterrevolution and revolt, Boston, Beacon Press, 1972. the late Marcuse's thought was committed to tell between a false and a true environmentalism on the base of these reflections on aesthetics. According to him, ecology can well be incorporated in capitalism if it does not claim for a radical change in the logic of exploitation of nature (humanity and nature) but only in some of its consequences. Today, for instance, "green" is the same economy of ever. A radical ecology, instead, understands the connection between the consequences and the inner logic of the capitalistic production because it follows other rules, other values, other desires, advocated by the aesthetic dimension: «This is the insurmountable internal limitation of any capitalist ecology. Authentic ecology flows into a militant struggle for a socialist politics which must attack the system at its roots, both in the process of production and in the mutilated consciousness of individuals» ${ }^{62}$.

62 Id., Ecology and revolution, in Id., Ecology and the Critique of Society Today, ed. by Sarah Surak, Peter-Erwin Jansen, Charles Reitz, Santa Barbara, University of California Santa Barbara, 2019, p. 5. 